Journal of Social Sciences 7 (3): 331-337, 2011

ISSN 1549-3652

(C) 2011 Science Publications

\title{
Socio-Economic Statues and Physical Activity Levels of 3th Grade Students: A Case Study in Istanbul Beykoz Province
}

\author{
${ }^{1}$ Pinar Salih, ${ }^{2}$ Kucuk Yetgin Meral, ${ }^{1}$ Kaya Fatih, ${ }^{2}$ Ozdol Yeliz and ${ }^{1}$ Biçer Bilal \\ ${ }^{1}$ Department of Athletic Training, \\ ${ }^{2}$ Department of Physical Education and Sports, Marmara University \\ ${ }^{3}$ Department of Athletic Training, Akdeniz University, \\ Physical Education and Sports, Turkey
}

\begin{abstract}
Problem statement: The children and adolescent period is critical time to acquire positive lifestyle habits. The aim of this study is to investigate the physical activity level of children aged between 9-10 accordance with their BMI's and socio-economic level of their school environments. This study also reviewed the articles about physical activity level of children, its relation to their socio-economic status and some other related tasks. Inactive life style sustained together with bad eating habits brings many healthy problems such as obesity and cardiovascular disease Approach: Technological development brings with it improving life style causing sedentary life for the public in developed and also developing Country. Physical activity can be viewed as a form of healthy life because it predicts functioning and adaptation and offers capabilities that enable people to live healthy. In this purposed three different socio-economic levels of six schools were determined accordance with declaration of National Education Department in Beykoz province. Each couple of school reflected one's Socio-Economic Status (SES). Totally 250 students from three different SES were participated (low-SES, $\mathrm{n}=92$; middle-SES, $\mathrm{n}=73$; high-SES, $\mathrm{n}=85$ ). Student's height and weight were measured and their Body Mass Index (BMI) was determined. BMIs were classified according to Cole's BMI tables which were underweight, normal, overweight and obese. Children Physical Activity Questionnaire (CPAQ), which is proposed by World Health Organization, was used for assessment of their Physical Activity Level (PAL). Data from the questionnaires was collected in a suitable relational database and analyzed with SPSS statistical package. Logit log linear analysis was applied to understand the trend of qualitative variables (SES, BMIs and PALs). Objective: The aim of this study is to investigate the physical activity level of children aged between 9-10 accordance with their BMI's and socio-economic level of their school environments. Results and Conclusion: It was observed that the effects of SES, gender and BMI on PAL were not statistically significant $(p>0.05)$. On the other hand, there were a significant interaction between PAL and SES $(p<0.01)$; PAL, SES and BMI $(p<0.05)$; and also PAL, SES and Gender $(p<0.05)$. The results would be more reliable when the study performed in big population and different provinces of the big cities in further studies.
\end{abstract}

Key words: Socio-Economic Status (SES), Physical Activity Level (PAL), Body Mass Index (BMI), Children Physical Activity Questionnaire (CPAQ), via accelerometry, skinny group, obese children, logit loglinear, pediatric clinicians, scholastic aptitude tests, metabolic equivalent

\section{INTRODUCTION}

Children who are overweight or obese are inclined to having such conditions in adulthood. Because of this participation in physical activity throughout the childhood, In addition to the continuation of normal growth within normal range (Faigenbaum et al., 2009).
The relationship of physical activity with health and motor development resulted in increased research related to this topic (Stodden et al., 2008). Although more research may be needed among youth to clearly determine the health and physical activity relationship, the health benefits of physical activity is clear (Haskell et al., 2007). It is well-documented in various studies that

Corresponding Author: Pinar Salih, Department of Athletic Training, Marmara University School of Physical Education and Sports, Turkey 


\section{J. Social Sci., 7 (3): 331-337, 2011}

regular aerobic exercise increases aerobic endurance and muscular power (Watts et al., 2005).

Physical activity participation of children and adolescents who are at risk for chronic diseases also need to be ensured (Flynn et al., 2006; Adegboye et al., 2010). Such participation reduces blood pressure in adolescents who reached critical limits, improves physical fitness in children with obesity (Jahangeer et al., 2010) and reduces overweight levels and so is reported as important. Such modalities increased awareness on the health benefits of physical activity and increased efforts to reduce sedentary lifestyles (Haskell et al., 2007). At this point, the need to determine level of physical activity participation became priority.

Some studies report that environment and socialeconomic conditions have significant role in the occurrence of overweight and obesity related to insufficient physical activity (Brownell et al., 2009; Fouad et al., 2010; Cita and Resmiati, 2010). Research findings show that physical activity is fundamental for health life and that it should continue for life and that the habit of physical activity is recommended to be gained during childhood (Hune et al., 2005; Romero, 2005).

In Turkey, weekly physical education times at schools were recently reduced. Physical activity locations and equipment for after school programs is not sufficient. Children are entering very competitive scholastic aptitude tests at very early ages. Such conditions result in less time spent for physical activity. Moreover, game and sport fields are not planned in most of urban areas (Isma1lov and Leatherdale, 2010) and the increased use of technology reduced physical activity. Such issues resulted in increased interest to the topic of concern.

Several factors affect the gaining of physical activity participation among elementary and middle school students. These are listed as the socioeconomic conditions of the school neighborhoods, physical educators' competency, school administrations susceptibility toward the youth sport opportunities, countries education and health politics Berry et al., 2010).

Reduction in physical activity participation is a health issue for children, adolescents and adults. Promotion of a more active lifestyle and determination of current activity levels becomes increasingly important under these circumstances. This study is an attempt to investigate the physical activity habits of 910 year old children via the use of body mass indexes and socio economic status of the schools neighborhood.

\section{MATERIALS AND METHODS}

Six schools are selected at the Beykoz region of İstanbul. The schools are picked from different socioeconomic regions within this region. The provincial 'National Education Directorate' assisted the researchers in this selection process. In this study, every pair of school represents a different socio-economic status. A total of 250 students' participated (107 females, 143 males); among which, 92 represented low Socio-Economic Status (SES), 73 represented middle SESand 85 represented high SES. Physical Activity Levels (PAL) of participants were determined using the World Health Organization's (WHO) physical activity questionnaire. Reliability and validity scores are calculated and found to be within the acceptable limits

The questionnaire consists of four parts sport activities, free time activities, school activities and home activities. Daily (both weekdays and weekends) physical activity for the last 7 days were investigated including the minutes spent. It is calculated by physical activity code and metabolic equivalent (MET) values (Ainsworth et al., 2000). PAL is calculated according to the formula below (Mahabir et al., 2006). 1 MET is defined as energy cost of a person per the sitting weight (in kg.) (Ainsworth et al., 2000). The children's PAL is grouped into 5 groups (low level, mid-low level, mid level, mid-highand high levels) (Sesso et al., 2000). This is followed the PALs dimension reduction into mid, mid-high and high levels. Participants are categorized according to their body mass index according to the table at Cole et al. (2000; 2007): Skinny, normal, overweight, obese (Table 1). However, there were a very small number of skinny group members so the evaluation is made among other group members. Human subject's clearance from National Educational Directorate and family approvals were secured before the data collection.

Table 1: BMI classification (Cole et al., 2000; 2007)

\begin{tabular}{|c|c|c|c|c|c|c|}
\hline \multirow[b]{2}{*}{ BMI classification } & \multicolumn{3}{|l|}{ Female } & \multicolumn{3}{|l|}{ Male } \\
\hline & 9 (age) & 9.5 (age) & 10 (age) & 9 (age) & 9.5 (age) & 10 (age) \\
\hline Skinny & $\leq 14.280000$ & $\leq 14.430000$ & $\leq 14.610000$ & $\leq 14.350000$ & $\leq 14.490000$ & $\leq 14.640000$ \\
\hline Normal & $14.29-19.1$ & $14.44-19.5$ & $14.62-19.9$ & $14.36-19.1$ & $14.50-19.5$ & $14.65-19.8$ \\
\hline Overweight & $19.2-22.80$ & $19.6-23.50$ & $20.0-24.10$ & $19.2-22.80$ & $19.6-23.40$ & $19.9-24000$ \\
\hline Obese & $\geq 22.900000$ & $\geq 23.600000$ & $\geq 24.200000$ & $\geq 22.900000$ & $\geq 23.500000$ & $\geq 24.100000$ \\
\hline
\end{tabular}


Physical activity energy cost (Mahabir et al., 2006):

PAEEQ $\left[\mathrm{kJ} \cdot \mathrm{kg}^{1} \cdot\right.$ day $\left.^{1}\right]=1440 \times\left[\left(0.0209 \times \mathrm{MET}^{*}\right) \times\right.$ (Total MET'min./Total durations)].

*MET (Harrell et al., 2005): 5, 92 ml.kg.min. for 8-12 years old boys and 8-11 years old girls.

Physical activity classification (Sesso et al., 2000):

- Low: $<2100 \mathrm{~kJ}$ week $^{-1}$

- Mid-Low: 2100-4199 kJ week ${ }^{-1}$

- Mid: 4200-8399 kJ week ${ }^{-1}$

- Mi-High: 8400-12599 kJ week ${ }^{-1}$

- High: $\geq 12600 \mathrm{~kJ} \mathrm{week}^{-1}$

Statistical analysis: The data is analyzed at the $p<.05$ significance level using SPSS program. Logit loglinear analysis is applied to see the gender effect with SES, BMI and FAD following the necessary reductions. Descriptive statistics are also used (mean, median,standard deviation, percent and frequency distributions).

\section{RESULTS}

Below, characteristics of male and female participants are provided according to their socioeconomic status (Table 2).

Below, characteristics of male and female participants are provided according to their body mass indexes (Table 3). Physical activity scores of male and female participants are provided according socio economic stats and BMI (Fig. 1).

According to the Logit Loglinear analysis; the effect of SES, gender and BMI on physical activity is not significant individually ( $p>05)$, yet, FAD $1 *$ SES 1 interaction $(\mathrm{z}=-2.593, \mathrm{p}=0.010), \mathrm{FAD} 1 * \mathrm{SES} 1 * \mathrm{BMI} 1$ interaction $(\mathrm{z}=2.203, \mathrm{p}=0.028)$ and FAD1*SES1*GENDER1 interaction is found to be significan $t(z=2.217, p=0.02)$.

According to these findings, children in low SES have mid level PA; children in low SES have normal level BMIand female participants in low SES have normal level BMI.

Table 2: Children's basic physical characteristics according to SES

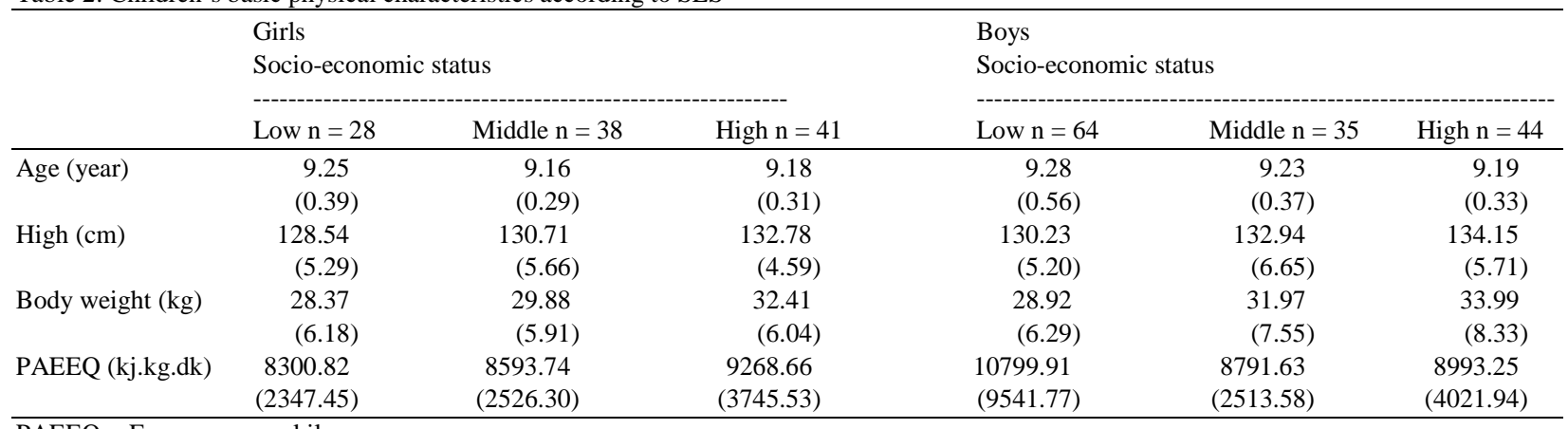

PAEEQ = Energy use per kilogram

Table 3: Children's basic physical characteristics according to BM

\begin{tabular}{|c|c|c|c|c|c|c|c|c|}
\hline & \multicolumn{4}{|c|}{$\begin{array}{l}\text { Girls } \\
\text { Body mass index }\end{array}$} & \multicolumn{4}{|c|}{$\begin{array}{l}\text { Boys } \\
\text { Body mass index }\end{array}$} \\
\hline & $\begin{array}{l}\text { Underweight } \\
\mathrm{n}=4\end{array}$ & $\begin{array}{l}\text { Normal } \\
\mathrm{n}=72\end{array}$ & $\begin{array}{l}\text { Overweight } \\
\mathrm{n}=18\end{array}$ & $\begin{array}{l}\text { Obesity } \\
\mathrm{n}=13\end{array}$ & $\begin{array}{l}\text { Underweight } \\
\mathrm{n}=4\end{array}$ & $\begin{array}{l}\text { Normal } \\
\mathrm{n}=102\end{array}$ & $\begin{array}{l}\text { Overweight } \\
\mathrm{n}=27\end{array}$ & $\begin{array}{l}\text { Obesity } \\
\mathrm{n}=10\end{array}$ \\
\hline Age (year) & $\begin{array}{l}9.30 \\
(0.47)\end{array}$ & $\begin{array}{c}9.22 \\
(0.36)\end{array}$ & $\begin{array}{l}9.13 \\
(0.25)\end{array}$ & $\begin{array}{l}9.07 \\
(0.03)\end{array}$ & $\begin{array}{c}9.32 \\
(0.45)\end{array}$ & $\begin{array}{c}9.25 \\
(0.49)\end{array}$ & $\begin{array}{c}9.23 \\
(0.38)\end{array}$ & $\begin{array}{c}9.17 \\
(0.29)\end{array}$ \\
\hline $\operatorname{High}(\mathrm{cm})$ & $\begin{array}{c}129.25 \\
(2.22)\end{array}$ & $\begin{array}{r}130.10 \\
(5.33)\end{array}$ & $\begin{array}{c}132.11 \\
(4.95)\end{array}$ & $\begin{array}{r}134.46 \\
(5.70)\end{array}$ & $\begin{array}{c}131.75 \\
(3.95)\end{array}$ & $\begin{array}{r}130.71 \\
(5.44)\end{array}$ & $\begin{array}{r}135.02 \\
(6.26)\end{array}$ & $\begin{array}{r}138.60 \\
(3.95)\end{array}$ \\
\hline $\begin{array}{l}\text { Body weight } \\
(\mathrm{kg})\end{array}$ & $\begin{array}{r}22.23 \\
(.94)\end{array}$ & $\begin{array}{l}27.86 \\
(3.58)\end{array}$ & $\begin{array}{l}34.42 \\
(3.76)\end{array}$ & $\begin{array}{l}41.85 \\
(4.02)\end{array}$ & $\begin{array}{l}23.40 \\
(1.58)\end{array}$ & $\begin{array}{l}28.06 \\
(3.55)\end{array}$ & $\begin{array}{l}37.37 \\
(4.82)\end{array}$ & $\begin{array}{l}50.09 \\
(6.52)\end{array}$ \\
\hline $\begin{array}{l}\text { PAEEQ } \\
\text { (kj.kg.dk)* }\end{array}$ & $\begin{array}{c}8168.50 \\
(2757.26)\end{array}$ & $\begin{array}{c}8789.31 \\
(2796.77)\end{array}$ & $\begin{array}{c}9006.56 \\
(3549.35)\end{array}$ & $\begin{array}{c}8567.54 \\
(3744.79)\end{array}$ & $\begin{array}{c}14744.75 \\
(10165.81)\end{array}$ & $\begin{array}{c}9678.22 \\
(7505.27)\end{array}$ & $\begin{array}{c}8835.59 \\
(2966.62)\end{array}$ & $\begin{array}{l}10988.60 \\
(6731.51)\end{array}$ \\
\hline
\end{tabular}




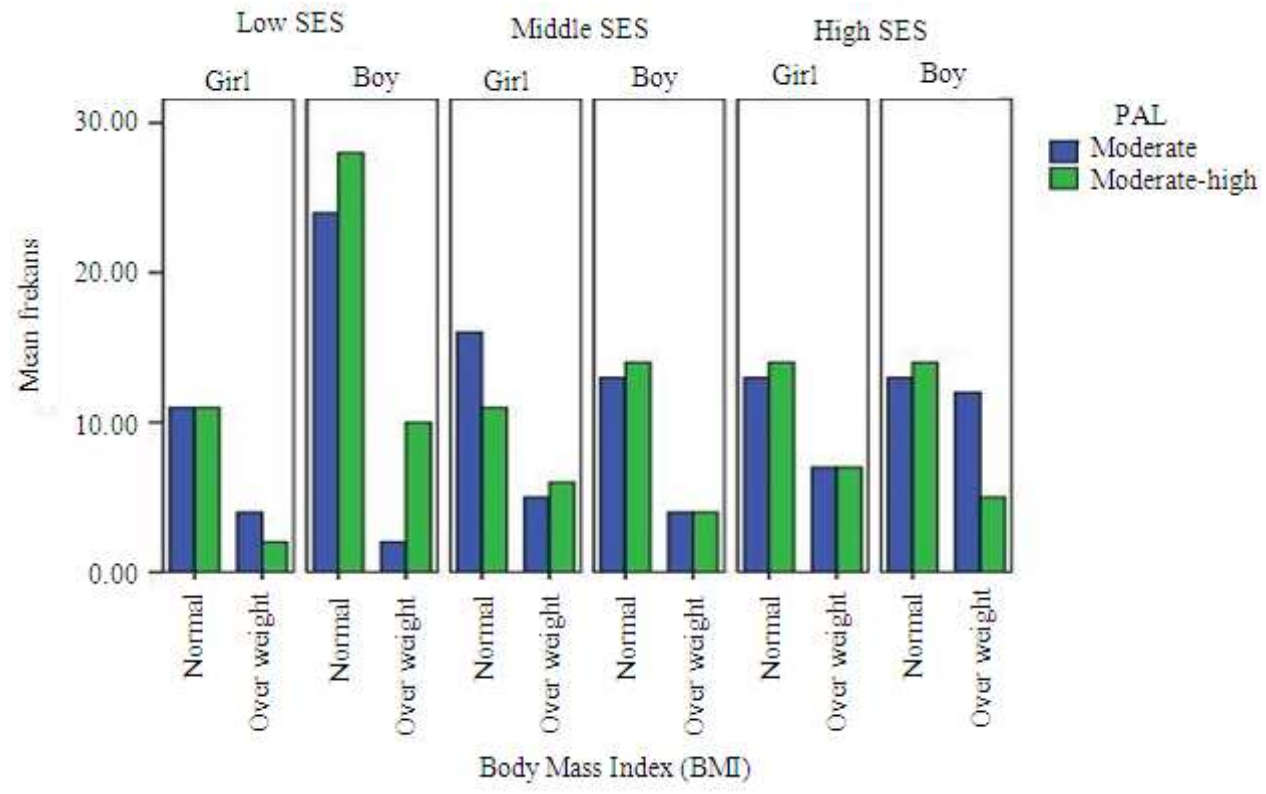

Fig. 1: The physical activity levels variations of boys and girls accordance with Socio-Economic Status (SES) and Body Mass Index (BMI)

\section{DISCUSSION}

Children from low SES families are at increased risk for unhealthy lifestyle and cardiovascular disease (CVD) in contrast to children from higher SES so the relation between low SES and health is not limited to adults (Pollitt et al., 2007).

Low socioeconomic position is widely reported to associate with high body mass index (BMI). (Borodulin et al., 2010). The results of this study showed that the children who were in low socio-economic level were mainly in moderate activity zone and mainly ranked as normal BMI level.

Turkey is considered to be a developing country. In developed countries, children and adults from the low socio-economic are more prone to obesity whereas it is the opposite in developing countries. Moraes et al. (2011) conducted an obesity prevelance study among 14 countries. According to the findings, abdominal obesity prevalence in developed countries ranges from $3.8-51.7 \%$, whereas the prevalence varies from $8.7 \%$ to $33.3 \%$ in developing countries. Same study reported that there are no consciences on the criteria for determining abdominal obesity. It is reported that children who have mothers with college degree have higher activity levels (McVeigh et al., 2004). The same study also reported that low activity and more TV watching children groups have families from lower SES (McVeigh et al., 2004). On the other hand, Dorsey et al. (2010). Suggested that the risk factors and self-or parent-reported risk behaviors routinely assessed by pediatric clinicians have limited ability to predict future growth trends, demonstrating the difficulty in determining which patients have the greatest risk of progression of obesity.

In an attempt to provide recent estimates of high BMI among children and adolescents and high weight for recumbent length among infants and toddlers and to analyze prevalence trends (1999 through 2008), The National Health and Nutrition Examination Survey was conducted. More than 3000 children and adolescents (2-19 years age) and about 700 infants and toddlers (0-2 years of age) participated. The only statistically significant linear trend in high weight for recumbent length or high BMI were among the very heaviest 6-19 year old boys (Ogden et al., 2010a). Same source reports that income has positive relationship with obesity among non-Hispanic white folks. From 1988 till 1994 and from 2005 till 2008, the only group that did not show obesity prevalence was girls whose head of household had a college degree (Ogden et al., 2010b).

There is difference between physical activity levels and eating habits. Male have tendency to be more active than female among all ages groups. Moreover, it is possible to claim that physically active adolescents have healthier eating habits in contrast to less active adolescents (Ottevaere et al., 2011). In contrast, results of this current study shows that most participants 'did not' make it to the recommended PAL. 


\section{J. Social Sci., 7 (3): 331-337, 2011}

Drenowatz et al. (2010) emphasize the importance of investigating more varying covariates like biological aspects (e.g. pre-natal environment, maternal behavior, post-natal influences) when investigating physical activity and/or sedentary behavior since results point to a more complex, multi-factorial phenotype. Findings show that children from low SES families are more inclined to sedentary activities and to have higher BMI but BMI, is also correlated with SES so untangling these associations is complicated. For more successful interventions, longitudinal studies to better understand any causal relationship between SES, BMI, sedentary behavior and physical activity during childhood is recommended (Drenowatz et al., 2010).

Ball et al. (2009) examined cross-sectional and longitudinal associations between Socioeconomic Position (SEP) and physical activity and sedentary behaviors amongst children $(n=184)$ and adolescents $(n=358)$. Separate assessment tools were used for these two groups and inear regression was used to predict physical activity and sedentary behaviors and changes in these behaviors, from maternal education. Although minimal potential relations documented between SEP and self-reported physical activity, they were insignificant and inconsistent in direction. Overall, findings did not support that maternal education did not predict children's physical activity or sedentary behaviors. Given the well-documented inverse relationship of SEP with physical activity levels in adult samples, findings suggest that such differences may surface after adolescence (Ball et al., 2009).

In a study carried out by Kudas et al. (2005) $76.1 \%$ of boys and $34 \%$ of girls are reported to be active following school times. The gender difference during school time is much higher. Among boys, 94.6\% participate in PA whereas only $17 \%$ of girls participate in PA (Kudas et al., 2005). In our current study, similar findings related to the mild to moderate physical activity participation tendencies among school-age children. Different from former findings, high PA participation are reported among girls in the overweight group and among males in the obese group. However, when these gender differences are evaluated statistically, PA level of students are similar in all body mass index categorizations.

\section{CONCLUSION}

In summary, study findings show that body mass index is not an effective factor to determine the PA level of children ages 9-10 and that gender difference is not observed. The applicable BMI measurement method to determine overweight and obese children is still under discussion. BMI may be affected from nonfat body mass and ethnic differences can result in varying results (Charbonneau-Roberts et al., 2005). Because of this, there is continuing need to determine physical activity and relationship between BMI at different societies and different socio-economic statutes. New studies on this topic may open door to new and meaningful horizons in physical activity research.

\section{REFERENCES}

Adegboye, A.R.A., A.A. Sigmund, F. Karsten, B.S. Luis and L.H. Berit et al., 2010. Recommended aerobic fitness level for metabolic health in children and adolescents: A study of diagnostic accuracy. Br. J. Sports. Med., 17. PMID: 20558527

Ainsworth, B., W. Haskell, M. Whitt, M. Irwin and A. Swartz, 2000. Compendium of physical activities: An updateactivity codes met intensities. Med. Sci. Sports Exerc., 32: 498-504. PMID: 10993420

Ball, K., V.J. Cleland, A.F. Timperio, J. Salmon and D.A. Crawford, 2009. Socioeconomic position and children's physical activity and sedentary behaviors: Longitudinal findings from the CLAN study. J. Phys. Act. Health., 6: 289-298. PMID: 19564656

Berry, T.R., J.C. Spence, C. Blanchard, N. Cutumisu and J. Edwards., 2010. Changes in BMI over 6 years: The role demographic and neighborhood characteristics. Int. J. Obesity, 34: 1275-1283. PMID: 20157324

Borodulin, K., Z. Catherine, S. Risto, E.M. Tomi and L. Tiina et al., 2010. Health behaviors as mediating pathways between socioeconomic position and body mass index. Int. J. Behav. Med. DOI: 10.1007/s12529-010-9138-1

Brownell, K.D., M.B. Schwartz, R.M. Puhl, K.E. Henderson and J.L. Harris, 2009. The need for bold action to prevent adolescent obesity. J. Adolescent Health, 45: 8-17. DOI: 10.1016/j.jadohealth.2009.03.004

Charbonneau-Roberts, G., H. Saudny-Unterberger, H.V. Kuhnlein and G.M. Egeland, 2005. Body mass index may overestimate the prevalence of overweight and obesity among the Inuit. Int. J. Circumpolar Health., 64: 163-169. PMID: 15945286

Cole, T.J., K.M. Flegal, D. Nicholls and A.A. Jackson, 2007. Body Mass Index Cut Offs to Define Thinness in Children and Adolescents: International Survey. BMJ, pp: 335-194. 
Cole, T.J., M.C. Bellizzi, K.M. Flegal and W.H. Dietz, 2000. Establishing a standard definition for child overweight and obesity worldwide: International survey. BMJ, 320: 1240-1243. DOI: 10.1136/bmj.320.7244.1240

Dorsey, B., K.M. Mauldon, R. Magraw, Y. Sunkyun and H.M. Krumholz, 2010. Do self- or parentreported dietary, physical activity and sedentary behaviors predict worsening obesity in children? J. Pediatrics, 157: 566-571. DOI: 10.1016/j.jpeds.2010.04.062

Drenowatz, C., C.E. Joey, A.P. Karin, W. Greg and H. Kate et al., 2010. Influance of socio-economic status on habitual physical activity and sedentary behavior in 8- to 11-year old children. BMC Public Health, 10: 214. DOI: 10.1186/1471-245810-214

Faigenbaum, A.D., W.J Kraemer, C.J. Blimkie, I. Jeffreys and L.J. Micheli et al., 2009. Youth resistance training: Updated position statement paper from the national strength and conditioning association. J. Strength Cond. Res., 23: S60-S79. DOI: 10.1519/JSC.0b013e31819df407

Flynn, M.A.T., D.A. McNeil, B. Maloff, D. Mutasingwa and M. Wu et al., 2006. Reducing obesity and related chronic disease risk in children and youth: A synthesis of evidence with 'best practice' recommendations. Obesity Rev., 7: 7-66. DOI: 10.1111/j.1467-789X.2006.00242.x

Fouad, H., N. AL-Bayaty, A. Baharuddin and M.A. Abdulla, 2010. The relationship between serum cotinine levels and periodontal status. OnLine J. Biol. Sci., 10: 54-59. http://www.scipub.org/fulltext/ojbs/ojbs1025459.pdf

Harrell, J.S., R.G. McMurray, C.D. Baggett, M.L. Pennell and P.F. Pearce, 2005. Energy costs of physical activities in children and adolescents. Med. Sci. Sport Exer., 37: 329-336. PMID: 15692331

Haskell, W.L., I.M. Lee, R.R. Pate, K.E. Powell and S.N. Blair, et al., 2007. Physical activity and public health updated recommendation for adults from the American college of sports medicine and the American heart association. Circulation, 116: 1081-1093.

DOI: 10.1161/CIRCULATIONAHA.107.185649

Hune, C., J. Salmon and K. Ball, 2005. Children's perceptions of their home and neighborhood environments and their association with objectively measured physical activity: A qualitative and quantitative study. Health Educ. Res., 20: 1-13. DOI: $10.1093 /$ her/cyg095
Isma1lov, R.M. and S.T. Leatherdale, 2010. Rural-urban differences in overweight and obesity among a large sample of adolescents in Ontario. Int. J. Pediatr. Obesity, 5: 351-360. PMID: 20053147

Jahangeer, C., H.K. Maleika, M.K. Naushad and J. Shehzada, 2010. The effect of risk factors on cardiovascular vascular diseases in mauritius. Am. Med. J., 1: 46-50. http://www.scipub.org/fulltext/amj/amj1146-50.pdf

Kudas, S., B. Ulkar, A. Erdogan and E. Çırç1, 2005. Ankara İli 11-12 yas grubu cocukların fiziksel aktivite ve bazı beslenme alıskanlıkları. Hacettepe J. Sport Sci., 16: 19-29. http://www.sbd.hacettepe.edu.tr/fulltext/2005_1_2. pdf

Mahabir, S., D. Baer, C. Giffen, B. Clevidence and W. Campbell et al., 2006. Comparison of energy expenditure estimates from 4 physical activity questionnaires with doubly labeled water estimates in postmenopausal women. Am. J. Clin. Nutr., 84: 230-236. PMID: 16825700

McVeigh, J.A., S.A. Norris and T. Wet, 2004. The relationship between socio-economic status and physical activity patterns in South African children. Acta Paediatr., 93: 982-988. PMID: 15303817

Moraes, A.C.F., R.P. Fadoni, L.M. Ricardi, T.C. Souza and C.F. Rosaneli et al., 2011. Prevalence of abdominal obesity in adolescents: A systematic review obesity reviews. Obes Rev. 12: 69-77. DOI: 10.1111/j.1467-789X.2010.00753.x

Ogden, C.L, Lamb, M.M., Carroll, M.D. Flegal, K.M., 2010a. Obesity and socioeconomic status in children and adolescents: United States, 20052008. NCHS Data Brief., 1-8. PMID: 21211166

Ogden, C.L., D.C. Margaret, R.C. Lester, M.L. Molly and M.F. Katherine et al., 2010b. Prevalence of high body mass index in US children and adolescents, 2007-2008. JAMA, 303: 242-249. PMID: 20071470

Ottevaere, C., I. Huybrechts, L. Beghin, M.M. CuencaGarcia and I. De Bourdeaudhuij et al., 2011. Relationship between self-reported dietary intake and physical activity levels among adolescents: The HELENA study. Int. J. Behav. Nutr. Phys. Act., 8: 1-8. DOI: $10.1186 / 1479-5868-8-8$

Pollitt, R.A., S.K. Jay, M.R. Kathryn, V.D.-R. Ana and Z. Donglin et al., 2007. Early-life and adult socioeconomic status and inflammatory risk markers in adulthood. Eur. J. Epidemiol., 22: 5566. DOI: 10.1007/s10654-006-9082-1

Romero, A.J., 2005. Low-Income neighborhood barriers and resources for adolescents physical activity. J. Adolescent Health, 36: 2583-2589. DOI: 10.1016/j.jadohealth.2004.02.027 
Sesso, H.D., R.S. Paffenbarger and I.M. Lee, 2000. Physical activity and coronary heart disease in men: The harvard alumni health study. J. Am. Heart Assoc., 102: 975-980. PMID: 10961960

Stodden, D.F., J.D. Goodway, S.J. Langerdorfer, M.A. Roberton and M.E. Rudisill et al., 2008. A development perspective on the role of motor skill compentence in physical activity: An emergent relationship. Quest, 60: 290-306. http://www.aahperd.org/naspe/grants/grants/loader. cfm?csModule $=$ security/getfile $\&$ pageid $=66820$
Watts, K., T.W. Jones, E.A. Davis and D. Green, 2005. Exercise training in obese children and adolescents: Current concepts. Sports Med., 35: 375-392. PMID: 15896088

Cita, Y.P. and Resmiati, 2010. The relationship between demographic factors and low birth weight infants. Int. J. Res. Nurs., 1: 25-28. http://www.scipub.org/fulltext/ijrn/ijrn1125-28.pdf 